Elias Aliprandis • Juliette Harris • Barney Yoo

Bruce D. Gelb - John A. Martignetti

\title{
Isolation, characterization, and mapping of four novel polymorphic markers and an H3.3B pseudogene to chromosome 9p21-22
}

Received: April 16, 1999 / Accepted: May 20, 1999

\begin{abstract}
Alterations in chromosomal region 9p21-22 are among the most frequently encountered cytogenetic changes present in a number of human malignancies. In addition, the causative genes of a number of hereditary cancers have been genetically mapped to this region. We describe the isolation and precise localization of four novel polymorphic markers and a previously identified marker, D9S1846, from this region. Moreover, we have identified a retroposon-rich area within this oncogenic region containing a processed H3.3B pseudogene flanked by an L1 sequence and an Alu element. Together, these finely mapped and ordered reagents should prove useful for genetic mapping, sequencing, and loss of heterozygosity studies of the 9p21-22 region.
\end{abstract}

Key words Chromosome 9p21-22 - Polymorphic markers · Histone H3.3B Pseudogene - Loss of heterozygosity · Retroposon

\section{Introduction}

Chromosomal region 9p21-22 is one of the most frequently deleted or translocated regions in human cancer (Mitelman 1994). Malignancies associated with alterations in this region include acute lymphoblastic leukemia, non-Hodgkins lymphoma, gliomas, pituitary adenomas, lung cancers, bladder tumor, ovarian cancer, and melanoma. Additionally, three hereditary cancers have been mapped to the region: diaphyseal medullary stenosis with malignant fibrous histiocytoma (Martignetti et al. 1999), familial melanoma

E. Aliprandis · J. Harris · B. Yoo · B.D. Gelb · J.A. Martignetti $(\bowtie)$ Department of Human Genetics

Mount Sinai School of Medicine, Box 1498, Fifth Avenue at 100th Street, New York, NY 10029, USA

Tel. +1-212-659-6744; Fax +1-212-849-2638

e-mail: jam@msvax.mssm.edu

B.D. Gelb · J.A. Martignetti

Department of Pediatrics, Mount Sinai School of Medicine, New

York, USA
(Cannon-Albright et al. 1994), and multiple familial trichoepithelioma (Harada et al. 1996). We describe the isolation, characterization, fine mapping, and ordering of four novel polymorphic markers, the previously identified marker D9S1846, and a processed replacement histone H3.3B pseudogene and its flanking L1 and Alu elements.

\section{Source and isolation of polymorphic DNA markers and an H3.3B pseudogene}

Two P1 clones and one PAC clone (731, 232, and 160 8P, respectively; Research Genetics, Huntsville, AL, USA) from the region were restriction enzyme digested and the resulting fragments were separated electrophoretically and transferred to a nylon membrane (NEN, Boston, MA, USA) using standard methods (Maniatis et al. 1982). The resulting Southern blot was hybridized with $\gamma^{32} \mathrm{P}$-ATP end-labeled di-, tri-, and tetranucleotide repeat $\left(\mathrm{CA}_{n}, \mathrm{ATA}_{n}, \mathrm{TAG}_{n}, \mathrm{GGAA}_{n}\right.$, and $\mathrm{GATA}_{n}$ ) oligonucleotides. The corresponding positively hybridizing fragments were isolated by gel purification and subcloned and sequenced. Of these 12 clones, 3 were shown to be polymorphic when analyzed with a CEPH genomic DNA pool (Coriell Cell Repository, Camden, NJ, USA). In order, centromere to telomere, and based on the clone of origin and type of repeat amplified, the markers were designated 232CA1, 160 8PGATA1, and 731CA1 (Fig. 1).

As part of the effort to identify novel genes from the 9p2122 region, a number of subcloned fragments from P1 clones were directly sequenced. In this manner, a processed histone H3.3B pseudogene was identified within the P1 clone 526 (Fig. 2). Sequence analysis of $3.6 \mathrm{~kb}$ revealed that the pseudogene was colinear with the four exonic coding sequences of the H3.3B gene (Albig and Doenecke 1997) including its $5^{\prime}$ - and $3^{\prime}$-UTRs, the four polyA signal sites, and terminated in a polyA stretch. The pseudogene also possessed an additional $12 \mathrm{bp}$ of sequence identity upstream from the reported coding start site reported by Albig et al. (1995). Alignment of the sequences revealed an overall homology of 79\% (1269/1613 bases). Interestingly, a partial L1 element and an Alu element 


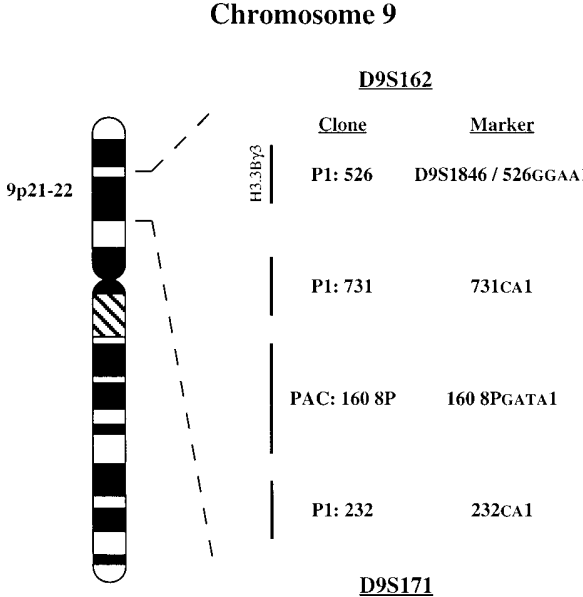

Fig. 1. Chromosome placement of markers and H3.3B pseudogene in the 9p21-22 region. The relative positions of the P1 and PAC clones relative to the previously ordered markers D9S162 and D9S171 are shown. Markers D9S1846 and 526GGAA1 are shown on the same line because their relative order has not been determined. The histone pseudogene is designated $\mathrm{H} 3.3 \mathrm{~B} \gamma 3$ because two other $\mathrm{H} 3.3 \mathrm{~B}$ pseudogenes have been previously described (Wells and Bains 1991)

directly flank the H3.3B pseudogene on either end. The subsequent insertion of these retroposons may have obscured the canonical flanking direct repeats that would have been generated following the retroposition of the H3.3B pseudogene.

Inspection of the 3.6-kb sequence revealed the presence of two polynucleotide-rich tracts flanking the pseudo-gene (Fig. 2). The $5^{\prime}(\mathrm{CA})_{n}$ dinucleotide-containing repeat segment was shown by BLAST search (http://www.ncbi.nlm.nih.gov/ BLAST/) to include the polymorphic microsatellite marker D9S1846. A novel 3'-tetranucleotide repeat marker, 526GGAA1, was shown to be polymorphic when amplified from a CEPH DNA pool.

\section{PCR primers}

Table 1.

\begin{tabular}{|c|c|c|}
\hline Primer Name & Sequence & $\begin{array}{l}\text { Average } \\
\text { size (bp) }\end{array}$ \\
\hline 232CA1F & $\begin{array}{l}\text { GTG ACA GAG TGA GAC TCC } \\
\text { ATC ATA TAT }\end{array}$ & 210 \\
\hline 232CA1R & $\begin{array}{l}\text { GCT TGG AGG TTC AGC CAA } \\
\text { TAT }\end{array}$ & \\
\hline 526GGAA1F & $\begin{array}{l}\text { TCC AGG GTG AAG ATA CAA } \\
\text { GTC }\end{array}$ & 350 \\
\hline 526GGAA1R & $\begin{array}{l}\text { GAC ACT ACA ATA CAT AAA } \\
\text { ATG GC }\end{array}$ & \\
\hline 731CA1F & $\begin{array}{l}\text { CGT TTC ATT GCA ACC CTA } \\
\text { ACC CT }\end{array}$ & 150 \\
\hline 731CA1R & $\begin{array}{l}\text { CCT CTT GCT TGT AGG CCT CTC } \\
\text { TT }\end{array}$ & \\
\hline 160 8PGATA1F & $\begin{array}{l}\text { GCA ATG TAC AGA ACA ATG } \\
\text { TAC ATG A }\end{array}$ & 210 \\
\hline 160 8PGATA1R & $\begin{array}{l}\text { GTT TTG CTT TAT TCT TCC AGG } \\
\text { ATT }\end{array}$ & \\
\hline
\end{tabular}

PCR amplifications were performed using AmpliTaq Gold (PerkinElmer, Norwalk, CT) according to the manufacturer's suggestions. Briefly, following the initial $10 \mathrm{~min} 95^{\circ} \mathrm{C}$ activation step, the reaction conditions were $\left[95^{\circ} \mathrm{C}\right.$ for $30 \mathrm{sec}, 56^{\circ} \mathrm{C}$ for $30 \mathrm{sec}$, and $72^{\circ} \mathrm{C}$ for $\left.1 \mathrm{~min}\right] \times 34 \mathrm{cycles}$ then $72 \mathrm{C}$ for $10 \mathrm{~min}$. Primer pair 232CA1 was annealed at $60^{\circ} \mathrm{C}$

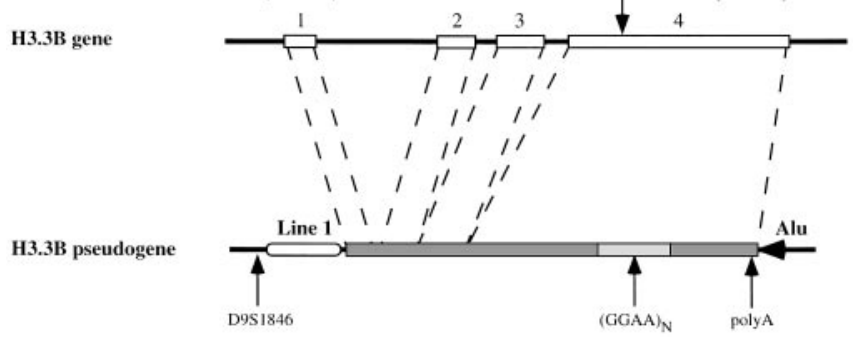

Fig. 2. The H3.3B pseudogene. Sequence alignment between the H3.3B (Albig et al. 1995) and $\mathrm{H} 3.3 \mathrm{~B} \gamma 3$ genes was performed using the program BLAST (http://www.ncbi.nlm.nih.gov/gorf/bl2.html). The four H3.3B exons are represented by open boxes and the dashed lines reveal the colinear regions between the two sequences. The relative positions of markers D9S1846 and 526GGAA1, the polyA strech, and flanking LINE 1 (oval) and Alu (arrow) sequences in the H3.3B pseudogene, and 5' and $3^{\prime}$ UTRs and termination signal (TGA) in the H3.3B gene are ahown

PCR conditions

The PCR was performed in a volume of $20 \mu$ l containing 10 ng of genomic DNA using AmpliTaq Gold (PerkinElmer, Norwalk, CT, USA) according to the manufacturer's recommendations. Cycle conditions were $95^{\circ} \mathrm{C}$ for $10 \mathrm{~min}$, then $32 \mathrm{cycles}$ of $95^{\circ} \mathrm{C}$ for $30 \mathrm{~s}, 55^{\circ} \mathrm{C}$ for $30 \mathrm{~s}$, and $72^{\circ} \mathrm{C}$ for $45 \mathrm{~s}$, with a final extension step of $10 \mathrm{~min}$ at $72^{\circ} \mathrm{C}$. Primer pair $232 \mathrm{CA} 1$ was annealed at $60^{\circ} \mathrm{C}$.

Acknowledgments The authors thank Maria Palmer and Deirdre Nazareth for excellent laboratory assistance. J.A.M. was the recipient of a Mentored Clinical Scientist Award (NIH K08 HD 1213-02) and a Young Pediatric Investigator Award of the Mount Sinai Child Health Center supported by an NIH grant (5 P30 HD28822). This work was supported by research grants from the American Academy of Pediatrics, Division of Human Genetics and Birth Defects; The Ruth Estrin Goldberg Grant for Cancer Research; and The Sinsheimer Scholar Award.

\section{References}

Albig W, Bramlage B, Gruber K, Klobeck HG, Kunz J, Doenecke D (1995) The human replacement histone H3.3B gene (H3F3B). Genomics 30:264-272

Albig W, Doenecke D (1997) The human histone gene cluster at the D6S105 locus. Hum Genet 101:284-294

Cannon-Albright LA, Goldgar DE, Neuhausen S, Gruis NA, Anderson DE, Lewis CM, Jost M, Tran TD (1994) Localization of the 9p melanoma susceptibility locus (MLM) to a 2-cM region between D9S736 and D9S171. Genomics 23:265-268

Harada H, Hashimoto K, Ko MS (1996) The gene for multiple familial trichoepithelioma maps to chromosome 9p21. J Invest Dermatol 107:41-43

Maniatis T, Fritsch EF, Sambrook J (1982) Molecular cloning: a laboratory manual. Cold Spring Harbor Laboratory Press, Plainview, NY

Martignetti JA, Desnick RJ, Aliprandis E, Norton KI, Hardcastle P, Nade S, Gelb BD (1999) Diaphyseal medullary stenosis with malignant fibrous histiocytoma: a hereditary bone dysplasia/cancer syndrome maps to 9p21-22. Am J Hum Genet 64:801-807

Mitelman F (1994) Catalog of chromosome aberrations in cancer, 5th edn. Wiley/Liss, New York

Wells D, Bains W (1991) Characterization of an unusual human histone H3.3 pseudogene. DNA Seq 2:125-127 